physics, fixed resistors, rotating electrical machines, measurement of current and voltage on high-voltage systems, storage and generation of electrical energy and the welding arc.

It is reported that work on the hydrogen-oxygen fuel cell has reached the stage at which a cell has been tested for more than $1,500 \mathrm{hr}$. and full-scale performance can now be predicted with confidence.

In relation to arc welding, it is stated that the surge injection system, a device developed by the Association which stabilizes the arc in the a.c. tungsten arc-welding process without generating radio interference and enables low-voltage plant to be used, is now in commercial production. 'There is also in this section a reference to the development of a novel method for the measurement of current at high voltage. This is a magneto-optical current transformer based on the Faraday effect.

Towards the close of the introduction, mention is made of a proposal to publish at intervals an $E R A$ Journal which would aim at bringing out the actual and possible impact of the Association's researches on industry ; the first issue of this journal appeared recently.

JAMES GREIG

\section{TECHNICAL INFORMATION SERVICES TO COMMERCE AND INDUSTRY}

$\mathrm{E}$ ARLY in 1955 the steering committee of the Regional Academic Board of the London and Home Counties Regional Advisory Council for Higher Technological Education asked its Librarianship Committee for advice on the feasibility of co-operation between county and municipal libraries in technical colleges, industrial firms and research associations in a given area to provide a scientific and technical information service which would be available to all local industrial and commercial concerns. Since that time the committee has examined schemes in operation, or planned, in the London and Home Counties region and in other parts of Britain.

Among these were the cities of liverpool and Sheffeld, a co-operative scheme between county boroughs in south-east Iaricashire, as well as one operated by the Hertfordshire County Council. The committee notes that, from the evidence available, the needs of industrial firms vary from area to area and recommends that the schemes in being at the places visited should be brought to the notice of municipal and county libraries, and to local committees of the British Productivity Council in the region with a suggestion that consideration might be given to the development of similar schemes on individual lines to suit local needs.

The technical colleges themselves can do much to stimulate the use by industry of scientific and technical information services in the following ways: by developing the college library to form a valuable part of the teaching programme; by fuller use of the college library in the teaching programme than is the general practice at the pregent time ; by training students in the use of the library's resources and other sources of information available to them in other libraries. If students are so trained during their years at college it is reasonable to expect that they will continue to turn to sources of information with which they are already familiar, in tackling the problems which face them later in industry and commerce. So, too, the link between the colleges and the industrial world will be progressively strengthened.

It is finally recommended that local education authorities in the region should consider what active steps may be taken to encourage the fuller use of libraries in teaching in technical and commercial colleges and that the teachers' organizations represented on the Regional Advisory Council should also be invited to give urgent consideration to this matter.

\section{MANAGEMENT BY SUPERVISION}

TN the world of industrial management it is becoming increasingly fashionable for lectures and articles to consist of exhortations or harangues by senior executives based on long experience in their particular firms. This, though useful, has its limitations, and it is refreshing to read a management journal where observations based upon original investigation are included. In the current issue of Personnel Management (38; September 1956), the organ of the Institute of Personnel Management, two articles describe researches which have been carried out by workers with experience in the field of social science. One of these, Nancy Wansborough, of the Acton Society Trust, has examined the effectiveness of internal advertising of vacancies as a means of making a demonstrably fairer system of promotion in industrial organizations. Her general conclusion is that the advantages of internal advertising outweigh the disadvantages, particularly in a firm where relations are already good. But in a firm where morale is low, employees may wonder whether advertisements are genuine or whether they are being used as a smoke-screen. In such circumstances, the introduction of advertising may make the last state worse than the first.

The second article has been contributed by Rensis Likert, director of the Institute of Social Research at the University of Michigan. Since 194.7 the Institute has been conducting a series of related studies seeking to find what kinds of organizational structure and what principles and methods of leadership and management result in the highest productivity, least absence, lowest turnover, and the greatest job satisfaction. Studies have been conducted, or are under way, in a wide variety of organizations. These include one or more companies in such industries as the following: public utilities, insurance, automotive, railroad, electric appliances, heavy machinery, textiles and petroleum. Studies have also been made in government agencies.

In general, the design of the studies has been to measure and examine the kinds of leadership and related variables being used by the best units in the organization in contrast to those being used by the poorest.

When foremen are asked what they have found to be the best pattern of supervision to get results, a substantial proportion, usually a majority, will place primary emphasis on getting out production. Other supervisors, whom Likert calls employee-centred, report that they get the best results when they place primary emphasis on the human problems of their workers. 
Higher levels of management, in discussing how they want their foremen to supervize, tend to place more emphasis on the production-centred approach as the best way to get results ; workers, on the other hand, tend to place less.

But which orientation yields the best results ? A variety of studies in widely different industries show that supervisors who are getting the best production, the best motivation and the highest levels of worker satisfaction are employee-centred appreciably more often that production-centred.

Related to orientation of supervision is closeness of supervision. Close supervision tends to be associated with lower productivity, and more general supervision with higher productivity. Low productivity at times leads to closer supervision; but it is clear also that it causes low productivity.

In one of the companies involved in the research programme it was found that switching managers of high- and low-production divisions resulted in the high-production managers raising the productivity of the low-production divisions faster than the former high-production divisions slipped under the lowproduction managers. Supervisors, as they were shifted from job to job, tended to carry with them and to maintain their habitual attitudes towards the supervisory process and towards their subordinates.

Investigations showed that the closer the supervision the less the productivity. Where supervision was more general, productivity increased, and this was accompanied by shifts in a favourable direction in attitudes, interests and perceptions. Workers became more interested and involved in their work, accepted more responsibility for getting the work done, and their attitudes towards the company and their superiors became more favourable; they accepted direction more willingly.

Where the supervision was close, all these attitudes and related variables shifted in an unfavourable direction. "All the hostilities, resentments, and unfavourable reactions which have been observed again and again to accompany extensive use of the scientific management approach manifested themselves." A fundamental conclusion from this experiment and similar research is that direct pressure from one's superior for production tends to be resented, while group pressure from one's colleagues is not.
Other experiments were concerned with the relationship between morale and productivity. It is generally believed by management that the higher the morale, the higher the production. Substantial research by Likert and others has shown that this relationship is much too simple. Some units have low morale and low production; other units have fairly good morale and low production; still others have fairly good production but low morale ; finally, other units have both high morale and high production.

Units with low morale and low production tend to have supervision which is laissez-faire in character and in which the leadership function has largely been abandoned. Units which have fairly good morale but poor production tend to have supervisors who try to keep people 'happy'. These supervisors are often found in companies in which human relations training programmes have been introduced and emphasized.

In the outstanding firms there is a kind of supervision which results in high production with high morale, high satisfactions and high motivation.

Making a plea for the rapid extension of research into management problems in industry and elsewhere, likert insists that every research project dealing with supervision and leadership shows how the most able supervisors and managers are struggling in company after company with trialand-error methods to discover how to improve their supervision.

It is possible to wait for this trial-and-error process gradually to evolve and to make clear what the new organization and management theory and processes will be. It would be faster and much more efficient to use the power of systematic research and experiment to accelerate their discovery and refinement. Those companies which support and co-operate in research to discover improved processes of management and to train their personnel will have a distinct advantage over companies which do not. Those which support research will discover at an earlier date the principles and practices which the successful companies of the future will be using and in which their own developing executives and managers should be trained. They will not experience the tragedy and cost of obsolete management which is so common in industry.

\section{THE FATE OF WILHELM HIS}

\section{By Dr. LAURENCE PICKEN}

The Library, Zoological Station, Naples

\begin{abstract}
"The experience of many years has taught me that phrases oft repeated finally ossify to conviction and utterly dull the organs of intuitive perception".

(Goetre: "On the Intermaxillary Bone".)
\end{abstract}

$I^{\mathrm{T}}$

is the fate of certain men of science to have made so great a mark on their century-distant generation that their names add lustre still to a bibliography, though their views (it is agreed), if not erroneous, are at least outmoded. Such names evoke a grateful sense of progress; they may be held up to the young as a warning against being unsound-; and of corruption there is no danger--for who would read a discredited though venerable author? This highly select company includes among others, and in varying degrees of membership, Lamarck, St. Hilaire and Lhrenberg; for many, Goethe; and unquestionably Wilhelm His, native of Basle, sometime professor of anatomy in the University of Leipzig.

'The object of this article is to direct attention to the imperfect manner in which knowledge of the work of His has been transmitted--an imperfection due to that unmerited indifference, already well established in his lifetime, of which Needham ${ }^{1}$ has considered the historical causes.

"I can well remember", wrote Sir D'Arcy Thompson $^{2}$, p. 84, "the harsh criticism and even contempt 